\title{
GMR
}

\section{Liguisticum wallichii inhibits renal carcinoma progression by downregulating UBE3A and through suppression of $\mathrm{NF}-\kappa \mathrm{B}$ signaling}

\author{
J.S. Wu ${ }^{1,2}$, P.M. Zhang ${ }^{1}$, L.J. Sun ${ }^{2}$ and X.Z. Liu ${ }^{3}$ \\ ${ }^{1}$ Department of Urology, the Affiliated Hospital of Weifang Medical University, \\ Weifang, Shandong, China \\ ${ }^{2}$ Department of Urology, Qiingdao University, Qiingdao, Shandong, China \\ ${ }^{3}$ Department of surgery, Weifang Medical University, Weifang, Shandong, China \\ Corresponding author: X.Z. Liu \\ E-mail: xianzhonglu2016@163.com
}

Genet. Mol. Res. 15 (4): gmr15049023

Received July 22, 2016

Accepted September 14, 2016

Published November 3, 2016

DOI http://dx.doi.org/10.4238/gmr15049023

Copyright (C) 2016 The Authors. This is an open-access article distributed under the terms of the Creative Commons Attribution ShareAlike (CC BY-SA) 4.0 License.

\begin{abstract}
Renal carcinoma accounts for a fifth of the morbidity among malignant tumors in China. Ubiquitin-protein ligase E3A (UBE3A) plays an important role in the occurrence and development of gene mutation-induced diseases. This study was designed to investigate the mechanism of Liguistium wallichii in treating renal carcinoma. Hematoxylin and eosin staining was applied to detect the pathological changes in a rat renal carcinoma model. The experimental group received $L$. wallichii treatment at $100 \mathrm{mg} / \mathrm{kg}$ every $48 \mathrm{~h}$ for 4 weeks, while the control group only received normal saline. The proliferation index Ki67 was measured by immunohistochemistry. Primary renal carcinoma cells were isolated and UBE3A expression was measured by quantitative polymerase chain reaction. The related signaling pathway was screened by the Pathway Finder Array. pP65 nuclear import was
\end{abstract}

Genetics and Molecular Research 15 (4): gmr15049023 
detected by immunofluorescence. A total of 60 rats were used for the renal carcinoma model, of which 58 rats were successfully established and equally divided into two groups: L. wallichii and normal saline. Ki67 expression decreased in the $L$. wallichii group and was upregulated in the normal saline group. Histological analysis showed significant renal cell nucleus division in the normal saline group. The UBE3A level decreased after $L$. wallichii treatment compared to the level in the normal saline group. The Pathway Finder Array revealed that the $\mathrm{NF}-\mathrm{\kappa B}$ signaling pathway was activated, and pP65 presented obvious nuclear import in the normal saline group. In conclusion, $L$. wallichii inhibits renal carcinoma progression by downregulating UBE3A and suppressing the NF- $\mathrm{KB}$ signaling pathway.

Key words: Liguistium wallichii; Renal carcinoma; UBE3A; NF-кB

\section{INTRODUCTION}

Renal carcinoma is a type of malignant disease in the urinary organ, and its survival rate is extremely low. One of the main reasons is that it can invade and migrate to peripheral tissues (Wieloch et al., 1996). The treatment of renal carcinoma has improved with advances in science and technology, but the overall survival rate is still low. Renal carcinoma treatment is a worldwide medical problem, and is difficult to be completely resected (Longa et al., 1989; Traina et al., 2011). Therefore, understanding the molecular mechanism of the invasion of renal carcinoma is quite important, especially for improved clinical treatment.

Ubiquitin-protein ligase E3A (UBE3A), also known as E6AP ubiquitin-protein ligase (E6AP) is an enzyme synthetized by the UBE3A gene, which is located on chromosome 15 (Xiong et al., 2000; Chung et al., 2010) and its relationship with inflammation and cancer has been widely investigated. The maternal UBE3A gene can be normally expressed, while the paternal gene cannot be expressed because of antisense RNA interference produced by the adjacent SNRPN gene (Gyenes et al., 2010; Britschgi et al., 2012). Recent studies have revealed that UBE3A participated in liver fibrosis by regulating HSCff6 in hepatitis (Alessandrini et al., 1999; Gonzalez-Zulueta et al., 2000). It was reported that UBE3A expression was reduced in breast cancer compared with mammary gland fibroma and further declined in severe breast cancer patients, suggesting that UBE3A plays an inhibitory role in breast cancer growth (Heiss, 1983). In addition, UBE3A has also been demonstrated to play an important role in the pathogenesis of prostate cancer and its higher expression was correlated with prostate cancer progression and specific death (Birch et al., 2014). However, the role of UBE3A in renal carcinoma remains poorly understood.

Ligusticum wallichii (ChuanXiong) is a Chinese medicinal herb that has been used orally with other herbs to treat heart and brain diseases. Previous studies have indicated the possible link between the plant and heart disease. L. wallichii could improve blood fluidity (Yan and Luo, 2002) and inhibit endothelial cell damage (Wang et al., 2013) and vascular smooth muscle cell proliferation (Liang et al., 2005). Several studies demonstrated that $L$. wallichii could be used to treat headache, pregnancy pain, post-natal bruising, new born pain, wind attack, migraines, schwindlig, pregnancy, postpartum abdominal pain and pediatric head pain (Ozawa et al., 1999; Sugino et al., 2000; Wu et al., 2000).

Genetics and Molecular Research 15 (4): gmr15049023 
Considering the role in regulating the expression of UBE3A (Horowitz and OspinaGiraldo, 2015), whether $L$. wallichii is involved in the development or pathogenesis of renal carcinoma remains to be elucidated. The aim of the present study was to explore the impact of L. wallichii on renal carcinoma and its related mechanism.

\section{MATERIAL AND METHODS}

\section{Renal carcinoma model establishment}

A total of 60 rats aged 8 weeks were purchased from Weifang Medical University. The 20-methylcholanthrene $(0.1 \mathrm{~g} / \mathrm{mL})$ was from Sigma. The thread was immersed in 20-methylcholanthrene and embedded into the kidney for 4 months to induce renal carcinoma. The experimental group received L. wallichii treatment at a dosage of $100 \mathrm{mg} / \mathrm{kg}$ every $48 \mathrm{~h}$ for 4 weeks, while the control group only received normal saline.

Rats were used for all experiments, and all procedures were approved by the Animal Ethics Committee of the Affiliated Hospital of Weifang Medical University.

\section{Primary renal carcinoma cell extraction}

The rats were dissected after anesthesia to extract renal tissue. Then, the tissue was collected in HBSS-2 fluid and grinded. Next, the cortical fragment was moved to HBSS-2 fluid containing $0.025 \%$ enzyme for digestion at $37^{\circ} \mathrm{C}$ for $15 \mathrm{~min}$. After washing with HBSS-2 fluid containing $10 \%$ fetal bovine serum twice, the fragment was cultured in primary cell medium (0.5 mM l-glutamine, $25 \mu \mathrm{M}$ l-glutamic acid, $2 \% \mathrm{~B} 27$, and $0.12 \mathrm{mg} / \mathrm{mL}$ gentamycin). The Petri dish was soaked in polylysine. The cells were seeded at $1 \times 10^{5} \mathrm{cells} / \mathrm{cm}^{2}$ and cultured at $37^{\circ} \mathrm{C}$ and $5 \% \mathrm{CO}_{2}$. The cells were used for experiments after 8 days cultivation.

\section{Quantitative polymerase chain reaction ( $q P C R)$}

The cells were added to Trizol and centrifuged at $4^{\circ} \mathrm{C}$ and $12,000 \mathrm{rpm}$ for $10 \mathrm{~min}$. The supernatant was moved to a new Eppendorf tube with a 1/5 volume of chloroform. After vibration for $15 \mathrm{~s}$, the liquid was centrifuged at $4{ }^{\circ} \mathrm{C}$ and $12,000 \mathrm{rpm}$ for $15 \mathrm{~min}$. After adding an equal volume of isopropanol, the liquid was further centrifuged at $4{ }^{\circ} \mathrm{C}$ and $12,000 \mathrm{rpm}$ for $15 \mathrm{~min}$. Then, the sediment was added with $75 \%$ ethanol [dissolved in diethylpyrocarbonate (DEPC) water] and centrifuged at $4^{\circ} \mathrm{C}$ and $12,000 \mathrm{rpm}$ for $5 \mathrm{~min}$. The RNA was dissolved in $20 \mu \mathrm{L}$ DEPC water after air drying. Next, RNA was reverse transcribed to cDNA using the kit (TaKaRa) for PCR. The primers used were as follows: UBE3A, F-GCCGGUCAUGUCCAAAGUATT, R-UACUUUGGACAUGACCGGCTT and GAPDH, F-GCCCTGAGGGCCCGAACTGTTACT, R-CAGACGCACGGCTTTGACCTTCTT. The PCR consisted of $95^{\circ} \mathrm{C}$ for $10 \mathrm{~min}$, followed by 40 cycles of $95^{\circ} \mathrm{C}$ for $30 \mathrm{~s}, 55^{\circ} \mathrm{C}$ for $30 \mathrm{~s}$, and $72^{\circ} \mathrm{C}$ for $30 \mathrm{~s}$. The melting curve was analyzed.

\section{Signaling pathway screening}

The Mouse Signal Transduction Pathway Finder ${ }^{\mathrm{TM}}$ (PAMM-014Z) was used for signaling pathway screening. Total RNA was extracted and centrifuged on a 96-well plate. The

Genetics and Molecular Research 15 (4): gmr15049023 
reaction system contained $2 \mathrm{X}$ RT2 SYBR Green Mastermix, $1 \mu \mathrm{L}$ cDNA, and $2 \mu \mathrm{L} \mathrm{ddH}_{2} \mathrm{O}$. The reaction was performed at $95^{\circ} \mathrm{C}$ for $10 \mathrm{~min}$, followed by 40 cycles of $95^{\circ} \mathrm{C}$ for $30 \mathrm{~s}, 55^{\circ} \mathrm{C}$ for $30 \mathrm{~s}$, and $72^{\circ} \mathrm{C}$ for $30 \mathrm{~s}$. The melting curve was analyzed.

\section{Hematoxylin and eosin (H\&E) staining}

The tissue was fixed in formalin and dehydrated. Next, the tissue was embedded and sliced at $4 \mathrm{~mm}$. After baking at $65^{\circ} \mathrm{C}$ for $1 \mathrm{~h}$, the tissue was dewaxed and stained with $\mathrm{H} \& \mathrm{E}$. After sealing, the section was observed under a microscope and diagnosed by three different pathologists.

\section{Immunofluorescence}

The cells were fixed and blocked with $10 \%$ bovine serum albumin for 50 min. After incubation with anti-pP65 primary antibody (Sigma, 1:100) overnight and secondary antibody (Santa, 1:100), the cells were stained with DAPI for 10 min. Finally, the cells were washed with phosphate buffered saline and observed under a microscope.

\section{Statistical analysis}

The data was analyzed using the SPSS11.0 software. A chi-square test was used for data comparison. An unpaired two-tailed Student $t$-test was used for the comparison of UBE3A expression between control and experimental groups. $\mathrm{P}<0.05$ was considered statistical significance. Each experiment was repeated at least three times.

\section{RESULTS}

\section{Ki67 expression in the renal carcinoma model}

Of a total of 60 rats, renal carcinoma was successfully established in $58(96.7 \%)$. Abdomen apophysis and H\&E staining were used as criteria for evaluating the changes. H\&E staining showed obvious nuclear division and large nuclei (Figure 1A). The experimental group received $L$. wallichii treatment at a dosage of $100 \mathrm{mg} / \mathrm{kg}$ every $48 \mathrm{~h}$ for 4 weeks, while the control group only received normal saline. As shown in Figure 1B, after L. wallichii treatment, Ki67 expression was reduced. However, it was upregulated in the normal saline group (Figure 1B).

\section{L. wallichii suppressed UBE3A activity}

A previous study showed that $L$. wallichii treatment can effectively suppress tumor activity. However, whether $L$. wallichii affects UBE3A expression remains poorly understood. qPCR was used to measure the expression of UBE3A after L. wallichii treatment, and it was revealed that the UBE3A level declined after treatment compared with the level in the normal saline group (Figure 2A). In addition, RNA was further used for Pathway Finder Array screening and it was found that $\mathrm{NF}-\mathrm{\kappa B}$ signaling pathway-related genes were upregulated in the normal saline group (Figure $2 \mathrm{~B}$ ). These data suggest that $L$. wallichii might regulate UBE3A expression or the NF- $\mathrm{KB}$ signaling pathway.

Genetics and Molecular Research 15 (4): gmr15049023 


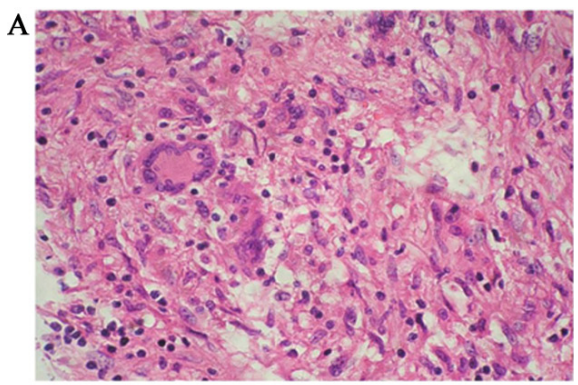

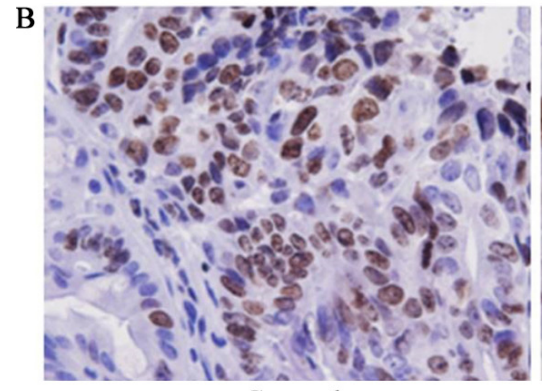

Control

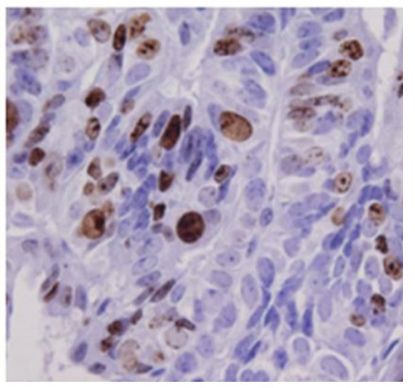

Experimental

Figure 1. A. Hematoxylin and eosin staining of renal carcinoma model. B. Ki67 expression in Liguistium wallichii treatment group.

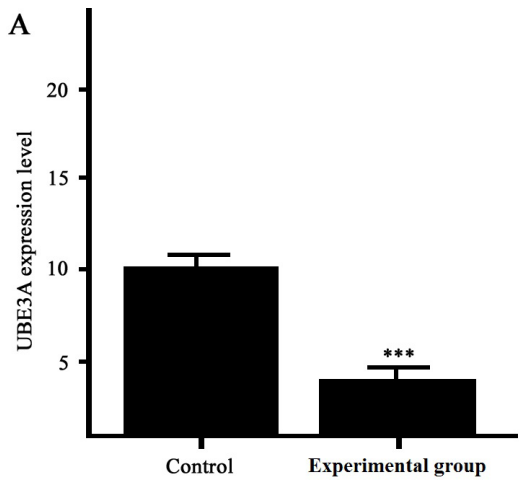

B

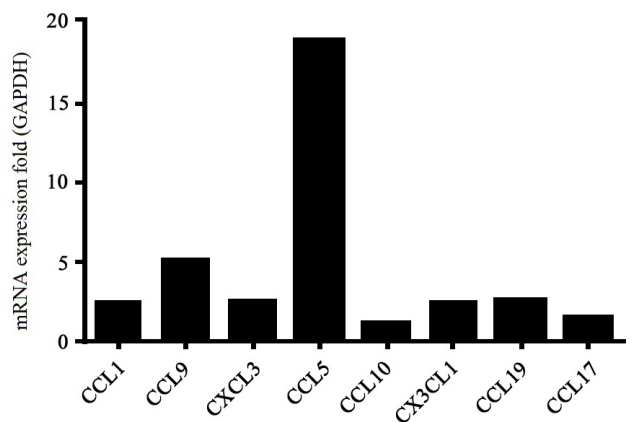

Figure 2. A. Ubiquitin-protein ligase E3A (UBE3A) expression in two groups. B. Pathway Finder Array screening of NF- $\kappa \mathrm{B}$ signaling pathway-related genes. $* * * \mathrm{P}<0.001$.

\section{L. wallichii inhibited NF-кB signaling pathway activity}

To further evaluate the effect of $L$. wallichii on the NF-kB signaling pathway, an immunofluorescent assay was performed, and it was demonstrated that the pP65 nucleus import obviously declined in the L. wallichii treatment group, suggesting that the NF- $\kappa \mathrm{B}$ signaling pathway was inhibited. On the contrary, pP65 presented obvious nuclear import in the normal saline group (Figure 3).

Genetics and Molecular Research 15 (4): gmr15049023 


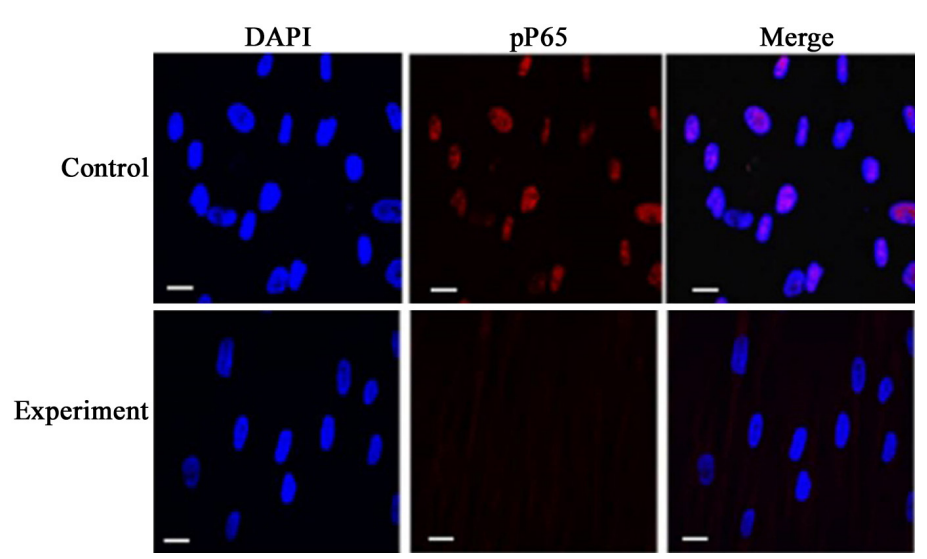

Figure 3. Liguistium wallichii treatment inhibited NF- $\mathrm{BB}$ activity.

\section{DISCUSSION}

Renal carcinoma has stronger invasion and a lower 3-year survival rate compared with other tumors. A recent study revealed that renal carcinoma can be characterized by immune cell infiltration, accompanied by stem cell and epithelial mesenchymal transition (Lechner et al., 2010). Microcirculation appears to be severely impaired and tissue ischemia edema is aggravated during cancer cell growth, leading to tissue ischemia and edema. This vicious cycle is responsible for genetic changes. In this process, excessive inflammation increases vascular permeability and release of inflammatory signal factors to reduce tumor deterioration (Seung et al., 1995). The inflammatory response has a close relationship with genetic changes. It was found that excessive UBE3A activation leads to cell proliferation in children. Zylka reported that importing the mutation to the animal model resulted in excessive growth of the subcutaneous transplantation tumor (Yi et al., 2015). Their findings pointed out that excessive UBE3A activation may be the cause of exuberant cell proliferation (Danna et al., 2004). Consistent with this finding, our results revealed that $L$. wallichii effectively downregulated UBE3A expression while retarding cell proliferation. Previous studies demonstrated that $L$. wallichii may change cell polarity (Amini et al., 2012), and this may affect UBE3A expression (Men et al., 2015). Thus, we speculated whether L. wallichii affects UBE3A expression by influencing the cell's polarity. Pathway Finder screening showed that the NF- $\kappa B$ signaling pathway presented significant changes. Immunofluorescence also detected that the pP65 nucleus import was decreased, suggesting that $L$. wallichii may reduce tumor cell proliferation by inhibiting UBE3A expression and suppressing NF- $\mathrm{KB}$ signal transduction.

$\mathrm{NF}-\kappa \mathrm{B}$ is a widely investigated signaling pathway, while NF- $\kappa \mathrm{B}$ pP65 nuclear translocation is critical for NF- $\mathrm{BB}$ signal transduction. It can regulate related targets to produce complicated physiological effects (Hock et al., 2003). For example, it participates in regulating cell growth, programmed cell death, and inflammation or immune response. NF- $\mathrm{kB}$ is also a common signaling pathway related to inflammation, whereas inflammation aggravation may lead to cancer. Upregulation of inflammatory factors can activate other inflammatory cytokines to form a positive feedback, eventually leading to inflammation generalization. Effective controlling of inflammatory cytokine release and alleviating the inflammatory response may block tumor cell proliferation. In line with this, our results confirmed that $L$. wallichii 
restrains renal carcinoma development through downregulating UBE3A and suppression of $\mathrm{NF}-\kappa \mathrm{B}$ signaling. However, the exact mechanism by how UBE3A regulates NF- $\kappa \mathrm{B}$ signal transduction remains unclear and requires further investigation. In addition, a previous study demonstrated that the MAPK signaling pathway was involved in the inhibition of cell growth in human renal cell carcinoma patients treated with docetaxel (Han et al., 2016). Whether $L$. wallichii affects the MAPK signaling pathway remains to be elucidated in the future.

In conclusion, our study demonstrated that $L$. wallichii restrains the progression and development of renal carcinoma through downregulating the UBE3A/NF- $\kappa B$ signaling pathway.

\section{Conflicts of interest}

The authors declare no conflict of interest.

\section{ACKNOWLEDGMENTS}

We thank the anonymous reviewers for reviewing this manuscript.

\section{REFERENCES}

Alessandrini A, Namura S, Moskowitz MA and Bonventre JV (1999). MEK1 protein kinase inhibition protects against damage resulting from focal cerebral ischemia. Proc. Natl. Acad. Sci. USA 96: 12866-12869. http://dx.doi. org/10.1073/pnas.96.22.12866

Amini FG, Rafieian-Kopaei M, Nematbakhsh M, Baradaran A, et al. (2012). Ameliorative effects of metformin on renal histologic and biochemical alterations of gentamicin-induced renal toxicity in Wistar rats. J. Res. Med. Sci. 17: 621-625.

Birch SE, Kench JG, Takano E, Chan P, et al. (2014). Expression of E6AP and PML predicts for prostate cancer progression and cancer-specific death. Ann. Oncol. 25: 2392-2397. http://dx.doi.org/10.1093/annonc/mdu454

Britschgi A, Andraos R, Brinkhaus H, Klebba I, et al. (2012). JAK2/STAT5 inhibition circumvents resistance to PI3K/ mTOR blockade: a rationale for cotargeting these pathways in metastatic breast cancer. Cancer Cell 22: 796-811. http://dx.doi.org/10.1016/j.ccr.2012.10.023

Chung KK, Tong X, Liu PD, McBride-Chang C, et al. (2010). The processing of morphological structure information in Chinese coordinative compounds: an event-related potential study. Brain Res. 1352: 157-166. http://dx.doi. org/10.1016/j.brainres.2010.06.069

Danna EA, Sinha P, Gilbert M, Clements VK, et al. (2004). Surgical removal of primary tumor reverses tumorinduced immunosuppression despite the presence of metastatic disease. Cancer Res. 64: 2205-2211. http://dx.doi. org/10.1158/0008-5472.CAN-03-2646

Gonzalez-Zulueta M, Feldman AB, Klesse LJ, Kalb RG, et al. (2000). Requirement for nitric oxide activation of p21(ras)/ extracellular regulated kinase in neuronal ischemic preconditioning. Proc. Natl. Acad. Sci. USA 97: 436-441. http:// dx.doi.org/10.1073/pnas.97.1.436

Gyenes A, Hoyk Z, Csakvari E, Siklos L, et al. (2010). 17ß-estradiol attenuates injury-induced microglia activation in the oculomotor nucleus. Neuroscience 171: 677-682.http://dx.doi.org/10.1016/j.neuroscience.2010.09.033

Han TD, Shang DH and Tian Y (2016). Docetaxel enhances apoptosis and G2/M cell cycle arrest by suppressing mitogenactivated protein kinase signaling in human renal clear cell carcinoma. Genet. Mol. Res. 15: 15. http://dx.doi. org/10.4238/gmr.15017321

Heiss WD (1983). Flow thresholds of functional and morphological damage of brain tissue. Stroke 14: 329-331. http:// dx.doi.org/10.1161/01.STR.14.3.329

Hock H, Hamblen MJ, Rooke HM, Traver D, et al. (2003). Intrinsic requirement for zinc finger transcription factor Gfi-1 in neutrophil differentiation. Immunity 18: 109-120. http://dx.doi.org/10.1016/S1074-7613(02)00501-0

Horowitz BB and Ospina-Giraldo MD (2015). The pectin methylesterase gene complement of Phytophthora sojae: structural and functional analyses, and the evolutionary relationships with its oomycete homologs. PLoS One 10: e0142096. http://dx.doi.org/10.1371/journal.pone.0142096

Lechner MG, Liebertz DJ and Epstein AL (2010). Characterization of cytokine-induced myeloid-derived suppressor cells from normal human peripheral blood mononuclear cells. J. Immunol. 185: 2273-2284. http://dx.doi.org/10.4049/ jimmunol.1000901

Genetics and Molecular Research 15 (4): gmr15049023 
Liang MJ, He LC and Yang GD (2005). Screening, analysis and in vitro vasodilatation of effective components from Ligusticum Chuanxiong. Life Sci. 78: 128-133. http://dx.doi.org/10.1016/j.lfs.2005.04.038

Longa EZ, Weinstein PR, Carlson S and Cummins R (1989). Reversible middle cerebral artery occlusion without craniectomy in rats. Stroke 20: 84-91.http://dx.doi.org/10.1161/01.STR.20.1.84

Men Y, Zhang A, Li H, Jin Y, et al. (2015). LKB1 regulates cerebellar development by controlling sonic hedgehogmediated granule cell precursor proliferation and granule cell migration. Sci. Rep. 5: 16232.http://dx.doi.org/10.1038/ $\underline{\text { srep } 16232}$

Ozawa H, Shioda S, Dohi K, Matsumoto H, et al. (1999). Delayed neuronal cell death in the rat hippocampus is mediated by the mitogen-activated protein kinase signal transduction pathway. Neurosci. Lett. 262: 57-60. http://dx.doi. org/10.1016/S0304-3940(99)00034-8

Seung LP, Rowley DA, Dubey P and Schreiber H (1995). Synergy between T-cell immunity and inhibition of paracrine stimulation causes tumor rejection. Proc. Natl. Acad. Sci. USA 92: 6254-6258. http://dx.doi.org/10.1073/ pnas.92.14.6254

Sugino T, Nozaki K, Takagi Y, Hattori I, et al. (2000). Activation of mitogen-activated protein kinases after transient forebrain ischemia in gerbil hippocampus. J. Neurosci. 20: 4506-4514.

Traina G, Federighi G, Macchi M, Bernardi R, et al. (2011). Modulation of myelin basic protein gene expression by acetylL-carnitine. Mol. Neurobiol. 44: 1-6. http://dx.doi.org/10.1007/s12035-011-8189-x

Wang GF, Shi CG, Sun MZ, Wang L, et al. (2013). Tetramethylpyrazine attenuates atherosclerosis development and protects endothelial cells from ox-LDL. Cardiovasc. Drugs Ther. 27: 199-210. http://dx.doi.org/10.1007/s10557013-6440-6

Wieloch T, Hu BR, Boris-Möller A, Cardell M, et al. (1996). Intracellular signal transduction in the postischemic brain. Adv. Neurol. 71: 371-387, discussion 387-388.

Wu DC, Ye W, Che XM and Yang GY (2000). Activation of mitogen-activated protein kinases after permanent cerebral artery occlusion in mouse brain. J. Cereb. Blood Flow Metab. 20: 1320-1330. http://dx.doi.org/10.1097/00004647$\underline{200009000-00007}$

Xiong L, Zhu Z, Dong H, Hu W, et al. (2000). Hyperbaric oxygen preconditioning induces neuroprotection against ischemia in transient not permanent middle cerebral artery occlusion rat model. Chin. Med. J. (Engl.) 113: 836-839.

Yan F and Luo R (2002). [Effects of ligustrazine on blood vessels and blood components]. Zhong Yao Cai 25: 143-145.

Yi JJ, Berrios J, Newbern JM, Snider WD, et al. (2015). An Autism-Linked Mutation Disables Phosphorylation Control of UBE3A. Cell 162: 795-807.http://dx.doi.org/10.1016/j.cell.2015.06.045

Genetics and Molecular Research 15 (4): gmr15049023 